\title{
A NEW PARADIGM OF REPARATION FOR VICTIMS OF CHILD \\ PORNOGRAPHY
}

\section{Suzanne Ost}

\begin{abstract}
This paper sets out the distinctive harm caused and wrong done to child pornography victims. It presents a paradigm of reparation within a restorative justice framework that explains the significance of material reparation for these victims. The paper demonstrates that because of the particular nature of child pornography offences and the harms and wrongs occasioned, existing avenues for legal redress in England and Wales and the United States are generally inadequate and ill-fitting and that a new mechanism for effecting suitable reparation is required. It concludes by sketching a new mode of restorative justice for victims of child pornography, emphasising significant matters that must be addressed alongside financial redress in order to facilitate victims’ restoration.
\end{abstract}

\section{INTRODUCTION}

The primary purpose of this paper is to suggest a novel approach to ensuring suitable reparation for child pornography victims in England and Wales and to reveal the shortcomings of existing avenues for redress under the current law. Its unique contribution is to formulate a new paradigm of reparation that reflects a restorative justice approach, understanding that the harm caused to child pornography (CP) victims is physical, psychological, emotional and ongoing. It argues that an appropriate mode of reparation must 
recognise the symbolic significance of emphasising the wrong that offenders have committed against victims and take into account the collective responsibility of: abusers, those who create CP; those who distribute this material; and those who download it. ${ }^{1}$ It also lays out other matters which must be addressed in order to facilitate victims' restoration in the broader context.

Whilst others have explored what would constitute appropriate reparation and restitution for victims of sexual offences, by and large the existing literature has concentrated on contact sexual offending such as rape or child sexual abuse, ${ }^{2}$ with almost no exploration of this issue with particular regard to CP victims outside of the USA. ${ }^{3}$ However, ensuring appropriate reparation for victims of $\mathrm{CP}$ is a matter of both practical and theoretical significance. In practical terms it is important for at least three reasons. First, CP is an especially egregious form of wrongdoing, and the profundity of the harm it causes has the capacity to remain ongoing throughout a victim's life. As discussed below, the image of a child being sexually abused is a permanent record of that abuse and, when the image is made available for others to download, the child’s privacy and dignity are subject to repeated infringement. The child’s awareness of the image and its availability to others can perpetuate their memory of the abuse

\footnotetext{
${ }^{1}$ It should be noted at the outset that although the CP victim's sexual abuse and its recording often occur in isolation from the distribution and downloading of the image(s) and may be perpetrated by different actors, the boundaries between creators and distributors can blur. For instance, one individual could be the abuser who creates the CP image and disseminates it. However, the creator could be a different individual from the distributor and, in most reported cases, the individuals who have downloaded images are not the child's abuser. Consequently, this paper treats the abuser/creator, distributor and downloader as different individuals.

2 See, e.g., B Hudson, 'Restorative Justice: The Challenge of Sexual and Racial Violence' (1998) 25 JLS 237; K Daly, 'Sexual Assault and Restorative Justice' in H Strang and J Braithwaite (eds), Restorative Justice and Family Violence (Cambridge: Cambridge University Press, 2002); A Cossins, 'Restorative Justice and Child Sex Offences' (2008) 48 Brit J Criminol 359; A-M McAlinden, 'Restorative Justice as a Response to Sexual Offending: Addressing the Failings of Current Punitive Approaches’ (2008) 3 Sexual Offender Treatment 1.

3 The sparse literature on this issue pertaining to the UK includes M Johnson, 'Seeking Damages for Child Pornography' (2011) 98 Personal Injury Law Journal 22; M Johnson and J Wheeler, 'Abusive Images of Children and Compensation' at http://www.boltburdonkemp.co.uk/articles/abusive-images-childrencompensation/ (last visited 9 December 2015). For literature relating to the position in the USA, see that referenced in Section 3(C) below.
} 
and exacerbate their psychological harm. ${ }^{4}$ The harm suffered by CP victims should thus be a matter deserving of the most attentive scrutiny on the part of lawmakers and reformers, yet this paper demonstrates that existing avenues for redress are ill-designed to address this harm and it is not captured by traditional causation principles. Secondly, as explained below, CP is a social evil to which a surprisingly wide range of participants contribute. ${ }^{5}$ In other words, the distinctiveness of the crime in terms of both gravity and scale ${ }^{6}$ demands that proper attention be afforded to devising an appropriate mechanism for effecting suitable reparation. Finally, the matter of reparation for CP victims has so far received very little legislative attention despite the existence of important international obligations in this regard. A UN Optional Protocol requires State Parties to 'take all feasible measures with the aim of ensuring all appropriate assistance to victims of such offences, including their full social reintegration and their full physical and psychological recovery' and to 'ensure that all child victims... have access to adequate procedures to seek, without discrimination, compensation for damages from those legally responsible'. ${ }^{7}$ These factors make the case for careful consideration of the salient issues all the more pressing.

The theoretical significance of the present enquiry centres on the fact that reflection on the question of how best to make reparation for victims of CP will inform more general debates about restorative justice in the modern era. Put otherwise, some of the arguments advanced

\footnotetext{
${ }^{4}$ See M Taylor and E Quayle, Child Pornography: an Internet Crime (Hove: Brunner-Routledge, 2003 ) p 24.

${ }^{5}$ See Taylor and Quayle, ibid, pp 4-5.

${ }^{6}$ See P Peachey, 'National Crime Agency says system realistically can't prosecute all 50,000 child sex offenders', The Independent, 20 October 2014.

${ }^{7}$ UN Optional Protocol to the Convention on the Rights of the Child on the Sale of Children, Child Prostitution and Child Pornography, A/RES/54/263, 25 May 2000, Article 9[3] and [4]. This Optional Protocol was signed by the UK on 7 September 2000 and ratified on 20 February 2009. Note also Article 20[2] of EU Directive 2011/93/EU on combating the sexual abuse and sexual exploitation of children and child pornography, which requires Member States to ensure that child victims have access to legal counselling and to legal representation 'including for the purpose of claiming compensation'.
} 


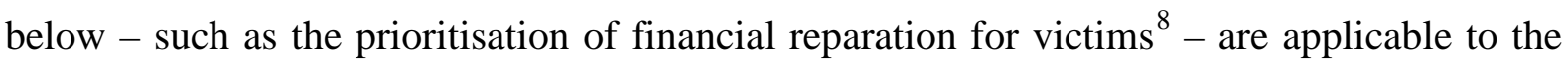
question of how to ensure suitable reparation for victims of other crimes. The article does not rest upon an assumption that $\mathrm{CP}$ is a more serious crime than any other. However, whilst some of the arguments it advances could be applied to other victims of different crimes, particularly sexual contact offences and perhaps adult victims of 'revenge porn', ${ }^{9}$ it is argued through an application of restorative justice principles that $\mathrm{CP}$ causes a distinctive harm which demands a particular form of reparation. There has been an ongoing debate as to the merits and demerits of utilising restorative justice in sexual offence cases since the 1990s. ${ }^{10}$ Drawing upon this debate, this paper steers away from initiatives that bring together offender and victim, such as conferencing, since it is argued that such schemes are inappropriate for CP victims, who may suffer more harm by being brought face to face with offenders. Moreover, because reparation for CP victims is the primary concern, the focus of the paradigm proposed is on restoring victims through material reparation rather than rehabilitating or reintegrating offenders. ${ }^{11}$

This paper unfolds as follows: Section 1 sets out the physical and psychological harm and wrong caused (the violation of privacy and dignity and exploitation of the child's abusive experience) to CP victims. It engages with literature on restorative justice in order to justify both the notion of harm adopted and the tailored approach to reparation that is subsequently advocated. Section 2 then proceeds to explain the significance of financial reparation for CP

\footnotetext{
${ }^{8}$ G Davis, Making Amends: Mediation and Reparation in Criminal Justice (London: Routledge, 1992), pp 168171.

${ }^{9}$ Whilst adult victims of revenge porn may also suffer psychological harm if they are aware that their image is available for others to view and a violation of their privacy (see the discussion in the text accompanying $n 123$ below), this paper is not directed towards adult pornography because of the distinction between child and adult pornography; the acts depicted in the former are criminalised since they are always considered to be harmful to the child and the recording of these acts is automatically a crime. See further S Ost, Child Pornography and Sexual Grooming: Legal and Societal Responses (Cambridge: Cambridge University Press, 2009) pp 31-32.

${ }^{10}$ See the literature referred to above, $\mathrm{n} 2$.

${ }^{11}$ For literature on how restorative justice initiatives can reintegrate and rehabilitate offenders, see McAlinden, above n 2; AM McAlinden, The Shaming of Sexual Offenders: Risk, Retribution and Reintegration (Oxford: Hart 2007).
} 
victims, suggesting a paradigm of reparation that sets out what should be achieved in this regard. This reveals that financial redress for these victims is radically different from standard kinds of compensation and should reflect both the harm and wrong committed in order to be symbolically significant. Section 3 explores the practical and theoretical inadequacies of existing legal avenues for redress. First, it discusses the possible avenues for reparation under the criminal and civil law in England and Wales from those who have caused harm to the child. It illuminates the difficulties posed by the complex array of persons and mechanisms that contribute to the causation of this harm and thereby demonstrates how the existing law fails to capture much of the harm and wrong that victims suffer. Secondly, it explores the model of restitution for victims of child sexual exploitation offences crafted in the USA. It becomes apparent that a straightforward legal transplant of the American model into this country would be impracticable and ill-advisable. In particular, difficulties associated with the twin concepts of causation and remoteness of damage can also clearly be evinced from the American experience. In the concluding section, a new mode of restorative justice for victims of CP is sketched. It is explained why a model of restorative justice involving diversion from the criminal justice system would be inappropriate and what the outlines of a scheme of material reparation might look like. Finally, to facilitate victims' restoration in the broader context, it is emphasised that there are other significant matters which must also be tackled in order to deal with the harm done. ${ }^{12}$

\section{The Harmfulness of CP as Viewed Through the Lens of Restorative Justice}

\footnotetext{
${ }^{12}$ It is important to emphasise that all potential avenues for reparation require that the victim is identifiable and can be found, a matter that will be returned to in the final section.
} 
Restorative justice approaches such as that advocated in this paper provide a response to crime premised on 'the fact that one person has been harmed by the wrongful actions of another ${ }^{13}$ and seek to redresses the harm caused. ${ }^{14}$ This necessitates a detailed consideration of the harm CP victims suffer at the outset in order to ascertain their specific needs and how those who have caused their harm can help address this harm. ${ }^{15} \mathrm{CP}$ involves the exploitation of children by numerous individuals. ${ }^{16}$ It is often preceded and facilitated by a process of grooming perpetrated by the abuser and designed to gradually desensitise the child to sexual abuse. ${ }^{17}$ This manipulative process is itself harmful and exploitative since the groomer: takes advantage of the child's trust and vulnerability; may show them CP images to help convince them that there is nothing wrong in what they are asking them to do; and a previously groomed child is more susceptible to future sexual abuse by others. ${ }^{18}$ Those who subsequently sexually abuse children and then record this abuse cause serious, enduring physical and mental harm to the children involved. ${ }^{19}$ Moreover, the existence of a photographic record of the abuse can serve 'to perpetuate the images and the memory of that abuse' ${ }^{20}$ In a study involving counselling and trauma therapists who had treated 76 victims of CP, it was found that all victims 'suffered from feelings of shame, hate and disgust or loathing', and the therapists revealed the victims' 'higher susceptibility to post-traumatic stress disorder, depression and psychoses'.21

\footnotetext{
${ }^{13}$ G Johnstone, Restorative Justice: Ideas, Values, Debates (Devon: Willan Publishing, 2002) p 64.

${ }^{14}$ McAlinden above n 2, p 2.

15 S. Sharpe, 'The Idea of Reparation', in G Johnstone and DW Van Ness (eds), Handbook of Restorative Justice (Cullompton: Willan, 2007) p 24, p 30.

${ }^{16}$ On such exploitation, see Ost, above $\mathrm{n} 9$, ch 3.

${ }^{17}$ Ost, ibid, pp 32-39 and 47.

18 A-M McAlinden, 'Grooming' and the Sexual Abuse of Children (Oxford: Oxford University Press, 2013) pp 129-130; and Ost, ibid and pp 136-137.

${ }^{19}$ For this reason, it has been argued that terms such as 'abusive images of children' are more appropriate than 'CP' (see Taylor and Quayle, above n 4, p 7). Nonetheless, the latter is used in this paper as it is a commonly recognised term, popularly understood to relate to images involving sexual abuse (see Ost, ibid, pp31-32). On the effects of child sexual abuse on victims, see D Finkelhor, Child Sexual Abuse: New Theory and Research (New York: The Free Press, 1984).

${ }^{20}$ Taylor and Quayle, ibid, p 24. See also Ost, above n 9, pp 118-120.

${ }^{21} \mathrm{~J}$ von Weiler, A Haardt-Becker and S Schule, 'Care and Treatment of Child Victims of Child Pornographic Exploitation (CPE) in Germany’ (2010) 16(2) Journal of Sexual Aggression 211, at pp 214 and 217.
} 
The severity of the harm caused to CP victims by abusers and those who record the abuse can be illuminated further by applying a living-standard analysis of harm caused by criminal offences. $^{22}$ In proposing a model which enables the gravity of harms to be compared, von Hirsch and Jareborg put forward a scale detailing four living standard levels that can be intruded upon by crime: (1) subsistence; (2) minimal well-being; (3) adequate well-being; and (4) enhanced well-being. Gravely harmful crimes such as murder affect the interests required for living standard (1) and can do so to the extent that they can deprive an individual of his life. ${ }^{23}$ Level (2) is defined as 'a minimal level of comfort or dignity', and includes ‘some degree of privacy and personal autonomy' and not suffering 'grossly demeaning' treatment. $^{24}$ Level (3) relates to 'maintenance of an "adequate" level (but no more) of comfort and dignity' and level (4) to 'significant enhancement in quality of life above the mere "adequate" level'. ${ }^{25}$ von Hirsch and Jareborg also introduce four interest dimensions that crimes intrude upon: physical integrity; material support and amenity; freedom from humiliation; and privacy/autonomy. ${ }^{26}$ The sexual abuse experienced by CP victims and the recording of it seriously intrude upon three of these four interests: physical integrity; freedom from humiliation; and privacy/autonomy. ${ }^{27}$ Victims’ living standards are affected at level (2) (minimal well-being) for they are deprived of a minimal level of comfort and dignity and receive grossly demeaning treatment. Consequently, the harm caused should be defined as serious. $^{28}$

\footnotetext{
${ }^{22}$ A von Hirsch and N Jareborg, 'Gauging Criminal Harm: A Living-Standard Analysis’ (1991) 11 OJLS 1.

${ }^{23}$ Ibid, p 18.

${ }^{24}$ Ibid.

${ }^{25}$ Ibid, pp 18 and 19.

${ }^{26}$ Ibid, p 20.

${ }^{27}$ See AA Gillespie, Child Pornography: Law and Policy (Abingdon: Routledge, 2011), p 31.

${ }^{28}$ von Hirsch and Jareborg, above n 22, p 29.
} 
Children who feature in CP are also victims of those who distribute and download images. Turning, first, to the harm that distributors and downloaders cause, it is exclusively psychological in nature, occurring when victims are aware of the distribution and downloading of the images by others. ${ }^{29}$ Considering again the interest dimensions that von Hirsch and Jareborg argue crimes intrude upon, dissemination and downloading impact upon CP victims' health (physical integrity) if their awareness of the availability of the images causes them to suffer mental distress, and also intrude upon their freedom from humiliation and privacy/autonomy. ${ }^{30}$ Yet as a matter of law and certain criminal law theory, dissemination and downloading can be perceived to amount to more remote, secondary forms of harm ${ }^{31}$ since they are both parasitic upon the initial abuse. Conceptualising the harm as a secondary harm has the potential to trivialise and downgrade the effects on the victim, however, because of the possible impression that it constitutes a 'lesser' harm. In contrast, when applying the lens of restorative justice, a fundamental concern is that we take full account of the effects of crime upon the victim, including psychological and emotional harm. ${ }^{32}$ Adopting such a tailored approach, the significance of the psychological harm that the CP victim suffers is emphasised, as is the fact that the psychological harm caused is ongoing once images have been made available on the internet. ${ }^{33}$ Consequently, a distinctive feature of the harm suffered by CP victims who are aware that the images are available for others to view is that their abusive experience and exploitation continues; there is no closure. As Leonard explains:

\footnotetext{
${ }^{29}$ For empirical evidence of this harm see von Weiler et al., above n 21, p 216 and M Leonard, "“I did what I was directed to do but he didn’t touch me”: The impact of being a victim of internet offending' (2010) 16 Journal of Sexual Aggression 249, p 252.

${ }^{30}$ [D]istribution of [CP] violates 'the individual interest in avoiding disclosure of personal matters...' New York v Ferber 458 U.S. 747 (1982), 759 n 10 per White J.

${ }^{31}$ See, e.g., D Baker, 'The Moral Limits of Criminalizing Remote Harms’ (2007) 10 New Criminal Law Review 370.

32 Sharpe, above n 15, p 30; Johnstone, above n 13, p 64; MS King, 'Restorative Justice, Therapeutic Jurisprudence and the Rise of Emotionally Intelligent Justice’ (2008) 32 Melb Univ Law Rev 1096, p 1098.

${ }^{33}$ See Leonard, above n 29, p 249.
} 
[Victims] are fully aware that they cannot remove the pictures from the internet... we cannot approach [them] as post trauma as they are still very much living and experiencing the trauma... at any time, on any day, in any country someone... could be looking at the pictures of them and using them as sexual stimulus for their own self-gratification. ${ }^{34}$

This suggests that the acts of distributors and downloaders are capable of affecting victims' living standards at level (2) (minimal well-being) and that the harm is serious. However, an issue that warrants consideration in the context of distribution and downloading is that of factual causation because, unless the victim is aware of a particular instance of such behaviour, it is impossible to argue that the individual who distributed or downloaded on that occasion (rather than any other) caused the victim’s psychological harm. ${ }^{35}$ But research reveals that what does occur is a form of cumulative causation which all distributors and downloaders contribute to. Victims are 'continually traumatized' by the awareness that others could be viewing the images. ${ }^{36}$ Theirs is a distinctive, collectively caused harm contributed to by a number of individuals at different times and places. Individual acts of distributing and downloading are therefore causative, although one such act in itself may be independently insufficient to cause the victim's psychological harm. Taking a strict approach to causation which fails to recognise such cumulative causation, and thereby fails to connect this harm with distributors and downloaders, would not satisfy the imperative of restorative justice to recognise who has caused the victim's psychological harm and to require that those persons

\footnotetext{
${ }^{34}$ Leonard, above n 29, p 254. See also J Martin, 'Child Sexual Abuse Images Online: Implications for Social Work Training and Practice’ (2014) British Journal of Social Work 1, 8; von Weiler et al., above n 21, p 216.

35 The difficulties this poses for victims when it comes to satisfying established legal principles of causation under existing potential avenues for redress will be discussed in the next section.

${ }^{36}$ Leonard, above n 29, p252; CG Svedin and C Back, Why Didn't They Tell Us? On Sexual Abuse in Child Pornography (Stockholm: Rädda Barnen, 2003) pp 65-66.
} 
make reparation. ${ }^{37}$ It would be at odds with the notion that 'reparation locates responsibility’ ${ }^{38}$

Turning, secondly, to the wrongs occasioned by distributors and downloaders, their intrusion upon CP victims' privacy and dignity is part and parcel of their abrogation of Kant's second categorical imperative which insists that a rational human agent must treat people always as an end and never as a mere means to an end. ${ }^{39}$ Distributors exploit the child's abuse by making it accessible for others to view and download, and those who seek out such images take advantage of the child for their own sexual gratification. Notably, these are wrongs that can occur even without the victim being aware of them. ${ }^{40}$ Indeed, if the focus is on the injury or wrong involved in the very acts of making available and downloading such images, when a victim becomes aware that this has occurred, she discovers that she has already suffered an injury for which a remedy is needed. The case for this remedy being one of financial reparation will now be made.

2. The Symbolic SignificANCE of FinANCIAL REDRESS FOR CP Victims: A PARAdigm OF MATERIAL REPARATION

\footnotetext{
${ }^{37}$ Sharpe, above n 15, p 30.

${ }^{38}$ Sharpe, ibid, p 29.

${ }^{39}$ I Kant, Groundwork of the Metaphysics of Morals in I Kant and MJ Gregor (ed), Practical Philosophy: (The Cambridge Edition of the Works of Immanuel Kant) (Cambridge: Cambridge University Press, 1999), p 37.

${ }^{40}$ For a full account of the wrongfulness entailed in violating another's privacy rights, even though the victim remains ignorant of this fact, see NA Moreham, 'Beyond Information: Privacy in English Law' [2014] CLJ 350, pp 352-355.
} 
Financial redress as of right for the harm and wrong suffered by victims of crime has been recognised as a central tenet of restorative justice, ${ }^{41}$ as has 'encouraging appropriate forms of reparation by offenders towards their victim,. ${ }^{42}$ This is not to say that restorative justice is only concerned with securing material reparation for victims. The idea of restoring victims has also been understood as repairing the relationship between victim and offender ${ }^{43}$ and some restorative justice models are focused on restoring offenders through encouraging offender responsibility and reintegration into society. ${ }^{44}$ However, this paper is not directed to the former since the conception of repairing a relationship does not fit well in any CP context which features numerous offenders with whom the child has no relationship; nor is it directed towards the matter of reintegrating offenders as its concern is restoring victims. It takes the stance that the primary objective must lie with 'vindicating the harms suffered by victims... and then, second, with rehabilitating offenders'. ${ }^{45}$ As such, its restorative justice approach is victim-oriented. $^{46}$

In light of the above analysis of the effects that CP crimes have on victims, a two-limbed paradigm of financial reparation which takes into account these harms and wrongs can be suggested:

(i) The victim has suffered a quantifiable harm which can be at least partly redressed by a monetary payment. In terms of possible redress, this harm could involve personal injury (physical and ongoing mental injury caused by the sexual abuse, the recording of this

${ }^{41}$ H Zehr, Changing Lenses: A New Focus for Crime and Justice (Scottdale PA: Herald Press, 1990) p26; Hudson, above n 2, p 254. See also R Barnett, 'Restitution: A New Paradigm in Criminal Justice' (1976) 87 Ethics 279.

${ }^{42}$ McAlinden (2008), above n 2, p 2.

${ }^{43}$ See, eg, K Pranis, 'Restorative Values' in Johnstone and Van Ness, above n 15, p 59.

${ }^{44}$ McAlinden (2007) and (2008), above nn 2 and 11. For an informative discussion of the different approaches, see Cossins, above n 2, pp 360-362.

${ }^{45}$ Daly, above n 2, p 84 (emphasis in original).

46 Johnstone, above n 13, p 83. For a critique of restorative justice approaches which place 'victims in the service of offenders', see Davis, above n 8, pp 165-167. 
abuse, and awareness of the image's availability for countless others to view and download) and financial costs (such as counselling costs and loss of earnings if her ability to work is affected).

(ii) The victim has suffered a wrong (her privacy and dignity ${ }^{47}$ have been violated and her abusive experience taken advantage of) which cannot be materially repaired or compensated, but for which a kind of moral reparation that involves a manifest recognition of the wrong, might be possible. Monetary payment from the offender can offer such reparation and carries a significant symbolic meaning, being 'tantamount to inviting the offender to admit to the victim that he was in the wrong' ${ }^{48}$

This draws attention to an important characteristic of CP cases that differentiates them from many other crimes, such as criminal damage or theft. In CP cases, it is impossible to ascribe a precise monetary value to the wrong that has been perpetrated. For this reason, financial reparation goes beyond simple compensatory aspirations and possesses an important symbolic aspect, especially, if such payments are made by the offender. ${ }^{49}$ In other words, financial redress can be understood to provide reparation to the victim if we focus on its association with the wrong done by the offender. ${ }^{50}$ This undoubtedly makes such reparations radically unlike standard kinds of compensation. Whilst the same argument might be made in the broader context of victims of sexual assault, the added dimension of CP within the sexual exploitation that victims experience calls for a distinctive legal response.

\footnotetext{
${ }^{47}$ It is recognised that there is no freestanding right to privacy or dignity at law, and thus the concepts are used in non-legal terms here. See, however, Section 2(B)(ii) for analysis of both concepts in relation to the tort of misuse of private information.

${ }^{48} \mathrm{~J}$ van Dijk, 'Ideological Trends within the Victims Movement' in M Maguire and J Pointing (eds), Victims of Crime: A New Deal? (Milton Keynes: Open University Press, 1988) p 125. See also Sharpe, above n 15, p 27.

49 See generally RA Duff, 'Repairing Harms and Answering for Wrongs' in J Oberdiek (ed), Philosophical Foundations of the Law of Torts (Oxford: Oxford University Press, 2014) p 212, p 227.

${ }^{50}$ Ibid, p221. See also L Zedner, 'Reparation and Retribution: Are They Reconcilable?' (1994) 57 MLR 228, pp 235 and 238.
} 
It would no doubt be easier to calculate a monetary value for reparation under the first limb of the paradigm than under the second limb, ${ }^{51}$ and matters are further complicated because actual cases are not likely to fit either limb in its pure form. Although it might be possible to offer separate payments for the harm referred to in (i) and the wrong stated in (ii), the two cannot necessarily be clearly separated 'for the wrong partly constitutes the relevant harm... when the harm is manifest in the victim's psychological suffering... [t]he victim's [distress] or fear expresses his understanding of what he suffered as a wrong....52 Notwithstanding this, identifying the wrong alongside the harm which is caused and the paradigm of reparation which follows illustrates the purpose - the symbolic significance - that financial reparation serves for CP victims. That said, whilst this paper adopts an approach that prioritises financial reparation, and research suggests that such reparation is important to victims of crime, ${ }^{53}$ the claim is not that material reparation in and of itself will fulfil the aim of restoring victims. ${ }^{54} \mathrm{~A}$ mode of reparation that could capture the harm and wrong laid out in the previous section and take forward the paradigm of reparation advocated in this section will be outlined in Section 4. However, prior to this, it is necessary to explore existing avenues for redress here and elsewhere and to demonstrate how these avenues are inadequate in providing suitable reparation for CP victims.

\footnotetext{
51 Albeit that the ongoing nature of the psychological harm adds to the complexity of deciding upon an appropriate monetary value. Although each case is specific to its facts, in RAR v GGC [2012] EWHC 2338 (QB) offers an example of how damages for the harm caused were calculated in a case involving CP.

52 RA Duff, 'Restoration and Retribution' in A von Hirsch, J Roberts et al (eds), Restorative Justice and Criminal Justice: Competing or Reconcilable Paradigms? (Oxford: Hart, 2003) p 43, p 48.

${ }^{53}$ Davis, above n 8, pp 170-171.

54 Johnstone, above n 13, p 63. Focusing on how to restore CP victims is in keeping with the notion of 'kaleidoscopic justice' that McGlynn has argued should lie at the centre of the response to sexual violence victims, for whom justice is 'lived and on-going'. See C McGlynn, 'Kaleidoscopic Justice: Justice and Victim Survivors of Sexual Violence’, at https://prezi.com/6mguhkw1tkre/kaleidoscopic-justice-making-sense-of-thelived-complexitie/ (last visited 9 December 2015). See Section 4 for consideration of how the utilisation of sufficient resources to both identify CP victims and offer tailored counselling support is essential to victims' restoration.
} 


\section{The Way in Which Harm is Construed and Might Be Redressed Through Legal}

\section{AVENUES FOR REPARATION IN ENGLAND AND WALES AND THE USA}

This section discusses the possible avenues for reparation in the context of the most appropriate party(ies) from whom to seek financial redress under the criminal law, or against whom to bring the civil action for damages in England and Wales, before exploring how CP victims might receive compensation in the USA. It reflects upon the question of whether these existing avenues capture the harm and wrong caused to the child and the likelihood of victims receiving reparation. It turns first to the possibilities offered through the criminal law in England and Wales.

\section{(A) Compensation under the Criminal Law in England and Wales}

(i) Criminalised behaviour in relation to $\mathrm{CP}$

The wrong and harm caused to victims noted above are recognised by the legislature and courts. The initial legislative response in 1978 was to criminalise the taking of an indecent photograph of a child, the distribution or showing of such a photograph and the possession of such a photograph with a view to distribution. ${ }^{55}$ Criminalisation was subsequently extended to cover possession in and of itself; ${ }^{56}$ pseudo-photographs and computerised photographs and electronic data capable of being converted into photographs; ${ }^{57}$ other behaviour related to encouraging, arranging or causing the involvement of a child in pornography; ${ }^{58}$ indecent

\footnotetext{
55 Protection of Children Act 1978, s.1. Knowingly downloading indecent images is commonly treated as the offence of making indecent images: $R$ v Smith, $R$ v Jayson [2002] EWCA Crim 683, although it as treated as possession for sentencing purposes. See Sentencing Council, Sexual Offences: Definitive Guideline (London: HMSO, 2013) p 76.

${ }^{56}$ Criminal Justice Act 1988, s160.

${ }^{57}$ Criminal Justice and Public Order Act 1994, s7(4) and (7).

${ }^{58}$ Child sexual exploitation offences under the Sexual Offences Act 2003 (SOA), ss48-50.
} 
photographs and pseudo-photographs of children aged sixteen and seventeen; ${ }^{59}$ and, most recently, non-photographic, pornographic images of children. ${ }^{60}$

Throughout this period of expanding criminalisation, judges have noted the harm-based rationale for $\mathrm{CP}$ offences in a way that resonates with a restorative justice conception of harm. For example, in $R \mathrm{v}$ Beaney, Keith $\mathrm{J}$ commented that: '... the offences which [downloaders] commit can properly be said to contribute to the psychological harm which the children in those images would suffer by virtue of the children's awareness that there were people out there getting a perverted thrill from watching them forced to pose and behave in this way'. ${ }^{61}$ Moreover, many of the aggravating factors to be taken into account in determining sentences in CP cases relate to the victim's harm. ${ }^{62}$ But does this recognition of the harm suffered mean that judges are likely to require the defendant to provide the victim with financial redress as part of the sentencing package imposed?

(ii) Reparation by way of a compensation order (from the abuser/creator, distributor and downloader)

In any criminal case where a victim suffers personal injury, ${ }^{63}$ loss or damage resulting from the offence, the court must consider making a compensation order. ${ }^{64}$ Compensation orders operate as an ancillary order to the principal sentence in criminal proceedings in order to bring reparation to the victim rather than to punish the offender, ${ }^{65}$ thereby reflecting

\footnotetext{
${ }^{59}$ By virtue of the SOA, s45.

${ }^{60}$ Coroners and Justice Act 2009, ss62-68. For analysis see S Ost, 'Criminalising Fabricated Images of Child Pornography: A Matter of Harm or Morality?’ (2010) 30(2) LS 230.

61 [2004] 2 Cr. App. R. (S) 82 [9] per Keith J.

62 See Sentencing Council, above n 55, p 78; Sentencing Council, Sexual Offences Guideline Consultation (London: HMSO, 2012) pp 12, 77 and 78.

${ }^{63}$ Including suffering by way of distress and anxiety: Bond v Chief Constable of Kent (1982) 4 Cr. App. R. (S) 314.

${ }^{64}$ Powers of Criminal Courts (Sentencing) Act 2000 (PCCSA), s130(1) and (2A).

${ }^{65}$ See further A Ashworth, Sentencing and Criminal Justice (Cambridge: Cambridge University Press, $6{ }^{\text {th }}$ edn, 2010) p 342; Criminal Justice Act 2003, s142(1)(e).
} 
restorative justice principles. It is for the court to decide what amount is appropriate, having considered any evidence and representations made by the defence or prosecution and the defendant's means. ${ }^{66}$ It is thus clear that the objective of restorative justice is constrained by practical and realistic concerns pertaining to the likelihood of the victim actually receiving the compensation. Failure to comply with a compensation order can lead to imprisonment, thus some kind of symbolic significance to the victim might be felt through extended imprisonment for the defendant who refuses to pay. But such symbolic significance is not experienced by the victim in cases where the judge chooses not to make a compensation order because the defendant cannot pay.

Case law has made it clear that the making of compensation orders would be inappropriate where there is uncertainty regarding the extent of any injury or damage, with such inquiries being better left to civil proceedings. ${ }^{67}$ In addition, whilst it is not necessary to establish that the loss resulted solely from the offence in question, it must 'fairly be said to result from the offence'. ${ }^{68}$ This does not bode well for cases involving CP convictions where assessing the particular defendant's contribution to the victim's overall harm is difficult. For instance, it may be that the offence in question is distributing the CP image. The child's mental suffering might be the result of a combination of the actual abuse, the recording of that abuse, the awareness that the image has been distributed by the offender and is now possessed by others who have downloaded it, and his understanding of the wrong committed against him (a combination of the damage identified in the proposed paradigm). Moreover, there may well be numerous offences and offenders acting independently from one another, ${ }^{69}$ including individuals who are not yet known and will never be known if their criminal behaviour goes

\footnotetext{
${ }^{66}$ PCCSA, s130(4) and (11); $R$ v Webb (1979) 1 CrAppR (S) 16.

${ }^{67} R$ v Donovan (1981) 3 Cr App R (S) 192, [4] per Eveleigh LJ.

${ }^{68}$ Rowlston v Kenny (1982) 4 Cr App R (S) 85, CA.

${ }^{69} \mathrm{Cf}$. the offence of affray and, e.g., $R \mathrm{v}$ Taylor (1993) $14 \mathrm{Cr}$ App R (S) 276.
} 
undetected. Consequently, the percentage of the overall harm caused by the defendant cannot easily be calculated.

This suggests that judges are less likely to make a compensation order in the case of a distributor or downloader than a creator who abused the child, because the child's harm is easier to attribute to the latter. Additionally, it is unusual for such orders to be made in CP cases. From 1985 to 2011, a compensation order was included in the sentence passed in just fifty-two cases involving indecent photographs of children. ${ }^{70}$ In part, the paucity of compensation orders in $\mathrm{CP}$ cases may be attributable to the fact that these cases tend to involve numerous images and victims' identities often remain unknown. ${ }^{71}$ It might also be because of a perception that financial compensation is not considered appropriate in such cases. $^{72}$

In sum, because of the nature of the criminal process and judicial discretion regarding sentencing, whether a compensation order is made is out of the victim's hands. Despite judicial recognition of the harm that $\mathrm{CP}$ victims suffer, they are unlikely to receive any reparation via a compensation order under the existing system, with the chances being somewhat more in their favour if the defendant is their (financially solvent) abuser.

\footnotetext{
${ }^{70}$ Personal communication from the Ministry of Justice dated 16 January 2013 (968-12 FOI 79753) and 13 January 2014 (1012-13 FOI 87598), on file with author. To put this into proportion, there were 7594 convictions for these offences between 1994-2007 (Gillespie, above n 27, p 6). More broadly, compensation orders were only awarded in 3.5 per cent of Crown Court cases in 2013. See Ministry of Justice, Criminal Justice Statistics Quarterly: December 2013: Sentencing Tables (2014), Table A5.17 at https://www.gov.uk/government/statistics/criminal-justice-statistics-quarterly-december-2013 (last visited 9 December 2015).

${ }^{71}$ The high number of cases in which victims are not identified has recently been noted by the Sentencing Council. See Sentencing Council, above, n 62, p 77.

72 This perception may have been encouraged by seemingly contradictory parts of the (now replaced) Sentencing Guidelines Council's Definitive Guideline for the SOA offences. See Sentencing Guidelines Council (SGC), Sexual Offences Act 2003: Definitive Guideline (London: HMSO, 2007) pp 108-114 and para 6.9. This Guideline was replaced on 1 April 2014 by the current Guideline (see Sentencing Council, above, n 55).
} 
(iii) Reparation through an application to the Criminal Injury Compensation Authority for compensation (for sexual abuse)

The state's Criminal Injuries Compensation Scheme (CICS) enables victims to recover compensation for 'crimes of violence' (including sexual assault) by applying to the Criminal Injury Compensation Authority (CICA). ${ }^{73}$ Awards for sexual assault take account of mental trauma besides physical and mental injuries ${ }^{74}$ and, specifically, awards range from $£ 1,000$ to $£ 44,000$ in the case of a sexual offence against a child. ${ }^{75}$

Whilst making CP or arranging or causing a child to be sexually exploited through involvement in pornography might amount to crimes of violence if violence or aggression against the child is used, it is highly doubtful that offences related to distribution or downloading (which are obviously not contact offences) ${ }^{76}$ would. Johnson has argued that these offences should amount to crimes of violence since CP 'is a crime of sexual exploitation, which can only take place by the abuse of children... The harm done to the child is the repeated invasion of the child's privacy'. ${ }^{77}$ But the difficulty is demonstrating how repeatedly invading a child's privacy is encapsulated by the CICS's construction of violent harm. If distributing and downloading images constitute crimes of violence, this would presumably mean that voyeurism could also be such a crime, which surely cannot be correct. $^{78}$

\footnotetext{
${ }^{73}$ Ministry of Justice, The Criminal Injuries Compensation Scheme 2012 (London: HMSO, 2012); Criminal Injuries Compensation Authority, A Guide to the Criminal Injuries Compensation Scheme (London: HMSO, 2012) section 2[4] and [10].

${ }^{74}$ Ibid, section 4[3].

${ }^{75}$ Ibid, Appendix 3, part B, 90-91.

${ }^{76}$ Notwithstanding this, in cases where the offender is over eighteen and has been sentenced to at least twelve months imprisonment, distributors and downloaders must comply with sex offender notification requirements. See SOA, Sched 3, [13] and [15].

${ }^{77}$ Johnson, above n 3.

${ }^{78}$ See also D Miers, 'Compensating Deserving Victims of Violent Crime: the Criminal Injuries Compensation Scheme 2012’ (2014) 34(2) LS 242, p 250.
} 
Following the introduction of the much-reduced CICS, ${ }^{79}$ any extension to the understanding of a crime of violence would not be accepted easily. Moreover, even if CP offences were to be construed as crimes of violence, the CICS may not offer an appropriate means of reparation since it could appear to all parties involved as being akin to a state welfare payment rather than redress which recognises the offender's responsibility for the victim's harm. ${ }^{80}$ It would thereby fail to reflect restorative justice principles and the moral reparation outlined in the second limb of the paradigm suggested earlier. Indeed, in the broader context, victims have cited a preference for receiving financial redress from offenders rather than the state. ${ }^{81}$

\section{(B) Civil actions under the law in England and Wales}

Seeking damages under the civil law may appear to be a less effective way for a CP victim to obtain reparation because, first, damages could have less of a symbolic value than financial redress paid by the defendant in recognition of the criminal wrong he has committed against the child. Secondly, the victim may not feel able to pursue a private claim: such an action could add to her mental suffering, and there is the significant matter of how her legal costs will be met. ${ }^{82}$ However, the lower burden of proof in civil law could be a possible advantage. Further, some victims might feel more empowered if they are able to pursue a civil action, ${ }^{83}$ and damages awards may be greater than those under the CICS because the CICA's tariff scheme is capped and, unlike the situation with compensation orders, the judge will not take

\footnotetext{
${ }^{79}$ Ibid, p 250.

${ }^{80}$ Johnstone, above n 13, p 74.

${ }^{81}$ H Strang, Repair or Revenge? Victims and Restorative Justice (Abingdon: Routledge, 2002) p 17.

${ }^{82}$ Legal aid can be made available in cases involving child abuse, but it is not granted as of right. Even in a 'no win no fee' arrangement, successful claimants must now pay after-the-event insurance premium out of their compensation (Legal Aid, Sentencing and Punishment of Offenders Act 2012, s44).

${ }^{83}$ See Duff, above n 49, p 219.
} 
into account the defendant's ability to pay. ${ }^{84}$ But pursuing reparation through civil law damages is only likely to provide reparation where the perpetrator has personal assets. ${ }^{85}$

A successful claim in a tort action could result in the victim recovering general damages for damage presumed to flow from the wrong, including pecuniary losses such as loss of earnings and non-pecuniary losses for pain and suffering. It may also be possible to recover exemplary (punitive) damages to punish and deter if the defendant was aware or recklessly disregarded the fact that his conduct was illegal in seeking to profit at the child's expense. ${ }^{86}$ What is more, infringements of dignity, such as that which occur in the CP context, might be compensated by aggravated damages, ${ }^{87}$ thus offering a potential means of realising the second limb of the reparation paradigm proposed earlier.

In what follows, the possible avenues offered by the torts of battery, the misuse of private information, and damages under the Protection from Harassment Act 1997 and the Data Protection Act 1998 are considered.

(i) Damages for sexual assault and the recording of this abuse (from the abuser/creator)

\footnotetext{
${ }^{84}$ See P Case, Compensating Child Sexual Abuse in England and Wales (Cambridge: Cambridge University Press, 2007) p 37; Ashworth, above n 65, p 325.

${ }^{85}$ As exemplified by A v Hoare [2008] UKHL 6. The principle of vicarious liability might be invoked to target a wealthier defendant (see, eg, Lister v Hesley Hall Ltd [2002] 1 AC 215. However, such an action would only be available in a case where the unauthorised acts are 'inextricably interwoven' with the duties of employment (per Lord Hutton, at 229). It is therefore very unlikely that the principle could be invoked where, e.g., an individual has distributed CP from, or downloaded images onto, his employer's computer.

${ }^{86}$ Rookes v Barnard [1964] AC 1129, 1227 (Lord Devlin's second class of cases in which exemplary damages could be awarded); John v Mirror Group Newspapers Ltd [1996] 3 WLR 593.

${ }^{87}$ See Rookes v Barnard, ibid, 1221 per Lord Devlin. Such damages have been awarded in, for instance, the torts of battery (eg, Appleton v Garrett [1996] 5 PIQR P1) and the misuse of private information (e.g., Campbell v MGN Ltd [2004] UKHL 22). See J Murphy, 'The Nature and Domain of Aggravated Damages' (2010) 69 CLJ 353, 358.
} 
The traditional civil law route under which children who have been sexually abused bring an action against their abuser is under battery for sexual assault. ${ }^{88}$ Battery requires no damage to be established and, if the defendant has been convicted, the victim could rely on the conviction as evidence of the facts. ${ }^{89}$ An action could be pursued where the individual who creates the CP has also physically abused the child, for it is axiomatic that battery involves touching the victim (thus excluding mere voyeurism or non-contact photography), and $R A R \mathrm{v}$ GGC evidences that compensation for the taking of images could be provided by way of aggravated damages. ${ }^{90}$ As noted above, case law has made clear that in less straightforward cases, it would be appropriate for the victim to seek damages through the civil law rather than for a compensation order to be made in criminal proceedings. Less straightforward cases could include ones where the child was abused by multiple abusers who have created images. Here, ascertaining the amount that a particular abuser has contributed to the victim's overall harm would certainly be more difficult and a civil law action thus more apt because joint tortfeasors are each liable for the whole of the damage inflicted. ${ }^{91}$

An action for battery against the creator/abuser is by far the most straightforward avenue for reparation open to CP victims. In cases of distribution and downloading images, whether a victim could sue is less clear-cut. In England and Wales, the current law offers little by way of any certain legal actions. It is also important to bear in mind the obvious point that in order to sue any given distributor or downloader, the child would first have to identify that individual as the wrongdoer. The distributor or downloader(s) may well be impossible to identify if their criminal behaviour has not been detected and the victim has not been linked

\footnotetext{
${ }^{88}$ Case, above, $\mathrm{n}$ 84, pp 54-59.

${ }^{89}$ On the limitation period, see Civil Evidence Act 1968, ss11 and 33; CXX v DXX [2012] EWHC 1535 (QB); $R A R$ v GGC [2012] EWHC 2338 (QB).

${ }^{90}$ Ibid.

${ }^{91}$ Contribution proceedings may be brought by one tortfeasor against another: Civil Liability Contribution Act 1978.
} 
to the images in question. However, in cases where distributor or downloader identification has occurred, the possibilities and necessary modification of legal principle and/or distorted representation of the damage done in the $\mathrm{CP}$ context that would be involved will now be briefly explored.

(ii) Damages for the misuse of private information (from the creator and distributor) Following case law, ${ }^{92}$ a CP victim could argue that she had a reasonable expectation of privacy regarding the image of her sexual abuse. The CP victim's private information is misused by individuals who create and distribute the image and, because the image is improperly and unlawfully obtained, the distributer could not raise a defence if the image was already in the public domain prior to his distribution of it. ${ }^{93}$ There is clearly no public interest in the image being disseminated. Indeed, given that account is taken of all the circumstances in deciding whether a reasonable expectation of privacy exists, ${ }^{94}$ the CP victim would surely have a stronger case than JK Rowling's son under this cause of action following the taking and publication of photographs of him in a public place. ${ }^{95}$ Could any information be said to be more private than that contained within a recording of a child being sexually abused, and the taking of such a photograph any more intrusive?

The tort of misuse of private information has been said to be 'fast developing' 96 and the tort's advancement by way of application to the CP context seems clearly apt. Consider also the judicial rationale cited for the extension of privacy rights beyond breach of confidence that 'the law is concerned to prevent the violation of a citizen's autonomy, dignity and self-

\footnotetext{
92 Campbell v MGN [2004] UKHL 22; Murray v Express Newspapers [2008] EWCA Civ 446; Mosley v News Group Newspapers [2008] EWHC 1777.

${ }^{93} D$ v L [2004] EMLR 1 [23].

${ }^{94}$ Ibid, [36].

${ }^{95}$ Murray, above n 92.

${ }^{96} \mathrm{D}$ v L, above n 93 [11], per Nicholls LJ.
} 
esteem' ${ }^{97}$ There is an obvious connection here with a restorative justice notion of harm and recognition of the wrong associated with the behaviour. Moreover, 'where fundamental values and essential aspects of private life are at stake, ${ }^{98}$ state obligations under Article 8 of the European Convention on Human Rights could extend into the sphere of relations of individuals between themselves. Thus, a failure to extend this cause of action to CP victims could lead to the contention that the protection offered against this wrongdoing through the civil law is inadequate and, therefore, a breach of Article 8.

If such a case were to be successfully brought, damages could be awarded in respect of distress and loss of dignity, ${ }^{99}$ but the issue of the proportion of damage caused might be relevant in the distributor's case if others have already made the image available. More importantly, it does not sit comfortably to frame the wrong caused to CP victims primarily as the misuse of private information. It captures some of the wrong which forms the basis of the second limb of the paradigm proposed earlier but not all of it, failing to convey the wrongdoer's taking advantage of the child's sexual abuse and his contribution to the ongoing nature of the child's suffering. It is also inappropriate to condense the harm and wrong done to victims in this way.

(iii) Damages for harassment under the Protection From Harassment Act 1997 (PFHA) (from the distributor)

The civil wrong of harassment under the PFHA requires a course of conduct amounting to harassment which the individual knows amounts to such. ${ }^{100}$ Harassment includes alarming a

\footnotetext{
${ }^{97}$ Mosely, above, n 92, [7] per Eady J. See also Campbell, above, n 92, [50] and [51] per Hoffman LJ.

${ }^{98} X$ and $Y \mathrm{v}$ Netherlands (1985) 8 EHRR 235.

${ }^{99}$ Mosely, above, n 92, [216].

${ }^{100}$ PRHA s1(1).
} 
person or causing them distress. ${ }^{101}$ The conduct must be 'oppressive and unreasonable' ${ }^{102}$ and it suffices if it is calculated in an objective sense to cause alarm or distress. ${ }^{103}$ Damages can be sought for anxiety caused by the harassment and any consequent financial loss. ${ }^{104}$ In interpreting 'course of conduct', ${ }^{105}$ it has been suggested that 'taking... an image, printing it, uploading and downloading are all separate acts'. ${ }^{106}$ If this is accepted, the PFHA may apply to the individual who commits all, or some, of these acts, such as a distributor who uploads the image more than once.

Further light is shed on whether distributors and downloaders could be sued under the PFHA by AMP v Persons Unknown. ${ }^{107}$ Here the claimant's mobile phone, which contained sexually explicit photographs of her for her boyfriend's personal use, went missing. Soon afterwards, the images appeared on an image-sharing website and her Facebook page was linked to them. The images were removed at her request; however, she was then contacted via Facebook by an individual who threatened to post the images online if she did not accept his friend request. A few months after she had refused this request, the images appeared on a site with her name appended to them. They were downloaded an unknown number of times by persons unknown. The claimant was granted an interim injunction to prevent the distribution of the images via downloading by persons who were unknown but traceable, ${ }^{108}$ since there was ‘a good arguable case’ that such conduct amounted to harassment. ${ }^{109}$

\footnotetext{
${ }^{101}$ PRHA s7(2).

102 Thomas v News Group Newspapers Limited and another [2001] EWCA 1233, [30] per Lord Phillips MR.

${ }^{103}$ Dowson v Chief Constable of Northumbria Police [2010] EWHC 2621 (QB), [142].

104 There is a six year limitation period. PRHA ss3 and 6.

105 The course of conduct must occur on at least two occasions: PRHA s7(3)(a); Lau v DPP [2000] 1 FLR 799, [15].

${ }^{106}$ Johnson and Wheeler, above $\mathrm{n} 3$.

107 [2011] EWHC 3454 (TCC).

108 Ibid, [14]-[20].

${ }^{109}$ Ibid, [45] per Ramsay J.
} 
It seems that the claimant suffered distress because of the connection that could be drawn between her and the images. For a CP victim, the link with the image is less conspicuous, not least because the original uploader will have avoided disclosing the child's name for fear of enabling identification and, thus, being connected to the offence(s). However, it is submitted that the harassment would be less related to the image being linked to the child (although this possibility may add to the child's mental distress) $)^{110}$ and connected more to the child's awareness that the image is available for anyone to see, as discussed in the first section.

The harassment in AMP was constituted by dissemination; downloaders facilitated distribution because the technology used by the site meant that downloading a file allowed pieces of that file to be uploaded by others. ${ }^{111}$ This suggests that it would be harder to prove that those who download CP but do not facilitate distribution commit this tort. However, where individuals disseminate or facilitate the dissemination of the victim's image, the fulfilment of the elements of 'oppressive and unreasonable' conduct and conduct calculated in an objective sense to cause alarm or distress in $A M P$ makes it probable that these requirements will be satisfied. ${ }^{112}$ This does involve a manipulation of an element of the tort though, since the intention of CP distributors is more likely to be the enhancement of reputation and/or to gain financially rather than to cause the victim distress. ${ }^{113}$ Moreover, if there are multiple distributors of the image, a victim will face the problem identified above of proving that the harm was caused by the particular defendant. Finally, considering the victim's suffering, it is important to bear in mind that the concept of harassment fails to reflect the full nature of the wrong and harm committed.

\footnotetext{
${ }^{110}$ See Martin, above n 34, p 8.

${ }^{111}$ Ibid, [12].

112 Ibid, [44].

${ }^{113}$ Taylor and Quayle, above n 4, pp 78, 94 and 207. Although see CEOP, Threat Assessment of Child Sexual Exploitation and Abuse (London: CEOP, 2013), p 8 [23].
} 
(iv) Damages under the Data Protection Act 1998 (DPA) (from the creator, distributor and downloader)

A final avenue for reparation might lie under the DPA. The Act applies to the processing of personal data, that is, information relating to a living individual who is identifiable from the data. ${ }^{114}$ Certain such data is 'sensitive personal data', ${ }^{115}$ and this is likely to include a photograph depicting a child engaged in sexual activity. Personal data is processed if it is obtained, recorded or held on any computer system, and if it is disclosed. The Act broadly defines a data controller as any individual who processes personal data; ${ }^{116}$ thus, an individual who creates CP through a computer, stores it on a computer, distributes it or acquires it through a computer, could be a data controller. ${ }^{117}$ Sensitive personal data should not be processed unless the subject gave explicit consent or there is a public interest in processing the data, ${ }^{118}$ neither of which would apply in the CP context. ${ }^{119}$

A person who suffers damage as a consequence of a data controller's failure to comply with the Act is entitled to compensation. ${ }^{120}$ Therefore, a CP victim may recover compensation for damage to her reputation, mental distress and financial losses, a form of reparation reflecting the first limb of the paradigm suggested earlier. ${ }^{121}$ However, there is the problem regarding who caused the harm in a case involving multiple offenders who may well remain unknown and this is especially so if the victim is looking to a downloader for

\footnotetext{
114 DPA, s1.

${ }^{115}$ s2(c) refers to data relating to an individual's sexual life.

116 Ibid.

117 See the explanation provided by A White, 'Data Protection and the Media', European Human Rights Law Review (2003) Supp 25, 26.

${ }^{118}$ DPA, Sch 3 [1-10].

${ }^{119}$ Other than legitimate processing of data by the police. See Protection of Children Act 1978, s1B.

${ }^{120} \mathrm{DPA}, \mathrm{s} 13$.

${ }^{121}$ It should be noted that there is uncertainty regarding how damage is defined for the purposes of the DPA. The Court of Appel held in Vidal-Hall v Google Inc [2015] EWCA Civ 311 that compensation could be awarded for distress alone without the need to prove financial loss, but this judgement is being appealed.
} 
compensation. ${ }^{122}$ Whilst downloading the image is one (more than trivial) cause of the harm, it would be difficult to establish the required sufficiently causative link between the particular instance of downloading and the victim's psychological suffering to enable recovery of compensation in tort. Case law suggests that causation may still be found in cases involving child sexual abuse despite the existence of other causes of the victim's condition, suggesting the possibility of a flexible, material contribution approach to causation. ${ }^{123}$ However, proving that it was the particular defendant's downloading that was a material contribution to the harm would be problematic. Furthermore, it is again inappropriate to condense the wrong into the misuse of personal data.

In sum, there is no easy way for CP victims to obtain reparation from those who contribute to their harm in England and Wales, with the legal principle of causation posing a significant obstacle. What is more, the harm and wrong caused are not adequately and appropriately recognised by any existing legal routes to redress. Have victims fared any better under the notably different approach in the USA?

(C) An alternative way of recognising harm and compensating CP victims? Restitution in criminal proceedings in the USA

A concept of restitution focused on recovering the victim's losses from the offender has a place in both American civil and criminal law. ${ }^{124}$ It is through federal restitution in criminal

\footnotetext{
${ }^{122}$ As Johnson has contended might be possible under the DPA: Johnson, above, n 3.

${ }^{123}$ See C v D [2006] EWHC 166 (QB) [100] and [102]. The judge applied Bonnington Castings Ltd v Wardlaw [1956] AC 613 and McGhee v National Coal Board [1973] 1 WLR 1.

${ }^{124}$ M Reid and C Collier, 'When Does Restitution Become Retribution?' (2012) 64 Oklahoma Law Review 653; J Marsh, 'Masha's Law: A Federal Civil Remedy for Child Pornography Victims' (2010-2011) 61 Syracuse Law Review 459. The legal conception of restitution under American law thus clearly differs from the conception under the law in England and Wales, which has at its base the idea of awarding the victim the defendant's gain-based damages. See J Edelman, Gain Based Damages: Contract, Tort, Equity and Intellectual Property (Oxford: Hart, 2002). Here, restitution is the remedy available in the entirely private law category of unjust enrichment. See P Birks, Unjust Enrichment (Oxford: Oxford University Press, 2003).
} 
proceedings that victims of sexual exploitation offences (including CP offences) ${ }^{125}$ have been singled out: following any conviction for such an offence from 2006, the Mandatory Restitution for Sexual Exploitation of Children Act requires restitution for the 'full amount of the victim's losses'. ${ }^{126}$ This includes costs incurred by medical services, physical therapy, lost income and 'any other losses suffered by the victim as a proximate result of the offense'. ${ }^{127}$ The victim can request that the prosecution seeks restitution, although the judge decides on the amount to be awarded.

The most popular contemporary conception of restitution's aim in federal criminal law is to compensate, ${ }^{128}$ with restitution being seen as 'an essential element in helping victims reconstruct their lives in the aftermath of a crime'. ${ }^{129}$ Indeed, the 'primary and overarching goal' of mandatory restitution in criminal proceedings is 'to fully compensate... victims for their losses and to restore [them] to their original state of well-being. ${ }^{130}$ In the context of CP victims, the lesser claim that '[a]n effective restitution memorandum that... seeks mental health and future lost income... can aid the victim on the path to healing, ${ }^{131}$ seems to recognise more realistically the limits of any attempt to provide reparation to CP victims and thereby achieve restorative justice. It cannot be possible to put victims in the position that they were in prior to the wrong perpetrated upon them, but providing redress for this wrong can assist them in their recovery from it.

\footnotetext{
${ }^{125}$ Such as employing or coercing 'any minor to engage in... any sexually explicit conduct for the purpose of producing any visual depiction of such conduct' and knowingly distributing and possessing such material (Chapter 110 of the U.S. Code (USC), §2251(a) and §2252A).

12618 U.S.C. $\S 2259(\mathrm{~b})(1)$.

${ }^{127}$ Ibid, (b)(3).

${ }^{128}$ RW Jacques, 'Amy and Vicky’s Cause: Perils of the Federal Restitution Framework for Child Pornography Victims’ (2010-11) 45 Georgia Law Review 1167, 1178. The courts have also emphasised a conception of restitution based on rehabilitation and deterrence: Kelly v Robinson 479 U.S. 36 (1986), 49, n 10.

${ }^{129}$ BA Fields, 'Restitution and Restorative Justice’ (2003) 22 Youth Studies Australia 44, 45.

${ }^{130}$ US v Simmonds 235 F.3d 826, 831 (3d Cir.2000) (emphasis added).

${ }^{131}$ A Downes, M Garvin, W Lucibello et al., 'Assessing Current Restitution Law to Effectively Serve Victims in Child Abuse Imagery Cases’ (2011) 22 Update 1, 5.
} 
$\S 2259$ was originally used successfully in cases involving child sexual abuse and the production of CP. ${ }^{132}$ However, since 2009, two victims named 'Amy' and 'Vicky' have sought restitution in over 800 federal and district court cases against defendants who possess and distribute images featuring them. ${ }^{133}$ Courts have been sharply divided in their reactions to these claims. In US v Staples, Amy was awarded restitution of over $\$ 3,000,000 .{ }^{134}$ In contrast, in another case she and Vicky were only awarded $\$ 6,000$ and $\$ 1,500$ respectively, ${ }^{135}$ and other courts rejected their claims altogether because of a failure to prove the particular defendant proximately caused their injuries, the difficulty of quantifying their losses, and the risks of overcompensation. ${ }^{136}$ For instance, in the District Court's judgment in US v Paroline, it was stated that Amy's losses 'are generalized and caused by her initial abuse as well as the general existence and dissemination of her pornographic images. No effort has been made to show the portion of these losses specifically caused by Paroline's possession of Amy's two images. ${ }^{137}$

One of the main controversies surrounding restitution in CP possession cases in the USA has, therefore, related to the complex matters of causation and remoteness. ${ }^{138}$ The approach of some federal courts has led to possessors being ordered to pay restitution for harm without the need to establish proximate causation (that is, that the damage was not too remote in the terminology used in England and Wales ${ }^{139}$ ) as required by $§ 2259 .{ }^{140}$ There was, in fact,

\footnotetext{
${ }^{132}$ D DiBari, 'Restoring Restitution: The Role of Proximate Causation in Child Pornography Possession Cases Where Restitution is Sought' (2011) 33 Cardozo Law Review 297, p 301.

${ }^{133}$ See further Reid and Collier, above n 124, p 657. Their lawyers receive notification when the images are discovered in an arrested individual's possession by virtue of the Crime Victims' Rights Act of 2004.

${ }^{134} 2009$ WL 2827204 (SD Fla Sept 2, 2009).

${ }^{135}$ US v Brunner 2010 WL 148433 (WDNC Jan. 12, 2010).

${ }^{136}$ See, eg, US v Paroline 672 F.Supp.2d 781 (2009); US v Aumais 656 F.3d 147 (2011); US v Fast 709 F.3d 712, 722 (8th Cir. 2013); Reid and Collier, above n 124, pp 657-58.

${ }^{137}$ Ibid, 792 per Davis J.

${ }^{138}$ Other criticisms include judicial confusion as to the method of calculating restitution. See Reid and Collier, above $n 124$.

139 ‘...[T]he requirement of proximate causation... would prevent holding any possessor liable for losses caused only in a remote sense'. Paroline v US 134 S.Ct. 1710 (2014), 1723, per Kennedy J.
} 
controversy regarding whether proximate causation was required for all harms listed under §2259. In Staples, ${ }^{141}$ for instance, the District Court awarded Amy restitution against the defendant who had six images which featured her on his computer. A psychologist gave evidence as to her suffering because of the defendant's possession of the images and this sufficed without the need to prove that he proximately caused the injuries. This led to the distinct possibility that some defendants were compensating the victim for a greater portion of the harm she had suffered than they themselves had caused. ${ }^{142}$ The US approach thus evidenced a failure to recognise what should constitute an appropriate level of reparation from individual offenders, taking into account their responsibility for the harm suffered by the victim, a position at odds with restorative justice principles. ${ }^{143}$

The matter of whether victims such as Amy and Vicky can recover damages from those found to be in possession of their images has now been addressed by the recent Supreme Court ruling in Paroline v US, albeit in a less than satisfactory way. ${ }^{144}$ A narrow majority held that Amy's losses resulting from the trauma of knowing that the images were being viewed by others were 'direct and foreseeable results of child pornography crimes'. However, 'but for' causation could not be found since 'it is not possible to prove that her losses would be less... but for one possessor's individual role in the large, loosely connected network through which her images circulate'. ${ }^{145}$ Thus, proximate causation was not established. Yet it was held that denying restitution would be at a variance with one of §2259’s penological

\footnotetext{
14018 U.S.C. §2259(b)(3)(F).

1412009 WL 2827204 (SD Fla Sept 2, 2009).

${ }^{142}$ Hence, DiBari contended that in such cases finding harm is equated with finding causation. DiBari, above, $\mathrm{n}$ 132, p 311. And see US v Paroline (2009), above n 136, p 791.

${ }^{143}$ See Sharpe, above n 15.

${ }^{144}$ US v Paroline, above, n 139.

145 Ibid, 1723, per Kennedy J. Nor was it appropriate to apply a less restrictive causation standard such as the aggregate causation test, which would hold that each possessor 'was part of a causal set sufficient to produce her ongoing trauma, so each possessor should be treated as a cause in fact of... all the attendant losses incurred as a result of the entire ongoing traffic in her images' (1724). According to the majority judgment, this would 'amount to holding each possessor... liable for the conduct of thousands of other independently acting possessors and distributors...’ (1725-1726).
} 
purposes: conveying to offenders the devastating harms that their behaviour causes to real victims. ${ }^{146}$ If, therefore, it could be established that the defendant's possession of images caused the victim to suffer loss because of the continuing traffic in her images, but the particular amount of those loses could not be traced back to the defendant through traditional causation principles, then restitution should be ordered in an amount reflecting that defendant's relative role in the causal process underlying her general losses. ${ }^{147}$ Kennedy J suggested that factors such as whether the defendant distributed as well as possessed the images, the number of past defendants found to have contributed to the victim's losses and a reasonably reliant estimate of the larger number of offenders involved (if available), could help determine the appropriate amount for a restitution award. ${ }^{148}$ He acknowledged that this approach would not be without its difficulties, ${ }^{149}$ and indeed, Roberts CJ noted in his dissent that even if it were 'possible to project the total number of persons who have viewed Amy's images, that number is tragically large, which... will lead to a pitiful recovery in every case'. ${ }^{150}$ That said, it might become a more feasible approach if a number of judgments emerge in which courts begin to set a standardised figure to reflect the extent to which continued trafficking in the victim's images has contributed to the victim's losses, and to appraise how much causal significance to attach to the behaviour of one individual who has played a role in this. ${ }^{151}$

\footnotetext{
${ }^{146}$ Ibid, 1726.

${ }^{147}$ Ibid, 1727.

${ }^{148}$ Ibid, 1728.

${ }^{149}$ Ibid, 1729.

${ }^{150}$ Ibid, 1734.

151 The difficulties posed by the Supreme Court's ruling can be seen in recent federal district court cases such as US v Crisostomi 31 F. Supp. 3d 361, 365 (D.R.I. 2014); US v Rogers 758 F.3d 37 (1st Cir. 2014) and US v Hanlon No. 2:14-CR-18-FtM-29DNF (M.D. FL. Jan. 23, 2015). In response to the Supreme Court's judgment, the Amy and Vicky Child Pornography Victim Restitution Improvement Act of 2015 (AVA) was introduced in January 2015 and passed by Senate in February 2015. The Act would set restitution amounts for CP victims and is currently being considered in the House. See https://www.congress.gov/bill/114th-congress/senatebill/295 (last visited 9 December 2015).
} 
The American approach, therefore, has been and is likely to continue to be steeped in controversy. In light of the Supreme Court's ruling in Paroline $\mathrm{v}$ US it is going to be challenging, to say the least, to assess the level of restitution in an amount that reflects the defendant's relative role in the causal process leading to the victim's general losses. Thus, the endeavour of achieving appropriate reparation for the $\mathrm{CP}$ victim is once again made extremely difficult by the twin issues of causation and remoteness under the alternative US model of restitution.

\section{Conclusion: Sketching A New Mode of Restorative Justice to AdDress the Harm CAUSED TO VICTIMS OF CP}

This paper has argued that the harm and wrong caused to CP victims is distinctive and this should be recognised in order for reparation to be both appropriate and symbolically significant. It has revealed that the possible avenues of redress under the current law in England and Wales fail to encapsulate the nature of the harm and wrong caused. It has also shown that these possible routes of redress and the US model of restitution are ill-suited to the aim of addressing the harm caused to victims because of the way in which requirements of causation and remoteness make it extremely difficult to attribute legal responsibility to downloaders in particular. In light of this analysis, this concluding section suggests what the outlines of a mode of reparation mirroring principles of restorative justice for $\mathrm{CP}$ victims might look like.

It is necessary, initially, to consider the appropriateness of certain RJ initiatives. In order to ensure a suitably tailored approach for $\mathrm{CP}$ victims, a new mode of restorative justice 
should not involve diversion from the criminal justice system. Much attention has been paid to restorative justice programmes which do involve such diversion, bringing the offender and victim together in an informal setting such as conferencing and mediation. ${ }^{152}$ Controversy continues to surround the utilisation of these initiatives in sexual offence cases ${ }^{153}$ and they do not form a part of the mode of reparation outlined here for a number of reasons. First, diverting sexual offences from the criminal justice system could send the wrong symbolic message, suggesting that the crime is somehow less serious. ${ }^{154}$ Although it might be countered that alternatives to the current criminal justice system would be less traumatic for sexual offence victims, ${ }^{155}$ this is much less likely to be the case for CP victims. This is due to a combination of: the ever-expanding criminalisation of behaviour related to $\mathrm{CP}$; the severe judicial and societal reaction to CP offences; ${ }^{156}$ the fact that if it is proven that some kind of sexual activity involving a child is photographed, this automatically constitutes CP; and the reality that, aside from offences relating to creating $\mathrm{CP}$, the victim is never involved in the trial process. ${ }^{157}$ It is thus harder to argue that diverting CP offences from the criminal justice system would be less traumatic for victims.

\footnotetext{
${ }^{152}$ See McAlinden, above n 2, p 3.

153 Cf. e.g., S Curtis-Fawley and K Daly, 'Gendered Violence and Restorative Justice: the Views of Victim Advocates' (2005) 11 Violence Against Women 603 and K Daly, 'Restorative Justice and Sexual Assault: An Archival Study of Court and Conference Cases’ (2006) 46 Brit J Criminol 334, with Cossins, above n 2.

${ }^{154}$ See the discussion in Daly, ibid, p 338. cf A-M McAlinden, 'Are There Limits to Restorative Justice? The Case of Child Sexual Abuse' in D Sullivan and L Tifft (eds), Handbook of Restorative Justice: A Global Perspective (London: Routledge, 2006) p 299, p 303.

155 Daly, ibid; MP Koss, KJ Bachar and C Quince Hopkins, 'Restorative Justice for Sexual Violence: Repairing Victims, Building Community, and Holding Offenders Accountable’ (2003) 989 Ann NY Acad Sci 384, p 387.

${ }^{156}$ See Ost, above n 9, chs 2 and 4. However, whilst not directly relevant to the CP context, it is noted that teenage victims of 'group localised grooming' have frequently been treated as though they were on trial by the criminal justice system. See J Mooney and S Ost, 'Group Localised Grooming: What is it and What Challenges does it Pose for Law and Society?’ (2013) 25(4) Child and Family Law Quarterly 425.

157 This is because of the nature of offences related to distribution and downloading, which do not directly involve the child. The offences are laid out above (Section 3(A)(i)). Also, in a trial related to the creation of CP, all special measures under the Youth Justice and Criminal Evidence Act 1999 would be available to protect CP victims.
} 
Utilising initiatives such as mediation in cases involving sexual offences also raises concerns that bringing the offender and victim together could be harmful and serve to perpetuate the power dynamic between the parties, concerns which clearly resonate for $\mathrm{CP}$ victims. Hudson, for instance, notes the danger that '... restorative processes [c]ould reproduce and reinforce the imbalance of power of the crime relationship, rather than confronting the offender with the power of the state acting on behalf of... the victim' ${ }^{158}$ In cases where the offender is the child's abuser or the creator of the CP with whom the victim had a relationship, there is a risk that bringing offender and victim together will increase the victim's vulnerability and re-traumatise her since, for child sex offences, 'the essence of the crime is manipulation, control, self-gratification and lack of empathy'. ${ }^{159}$ Whilst in other contexts, the potential that an offender's apology to his victim in a conference or mediation setting offers to recognise the wrong committed is apparent, ${ }^{160}$ utilising this variant of restorative justice could raise serious concerns for CP victims. For an offender who has groomed the child, it may be part of his strategy to gain access her again. ${ }^{161}$ Victims' recovery may also be impaired if they come face to face with or receive a letter from those who have distributed or downloaded their images. Knowledge of the name and face of an offender previously unknown to them may exacerbate their mental distress. ${ }^{162}$ That said, Leonard's research suggests that discovering the identity of perpetrators who view the images can assist CP victims in their recovery and, indeed, remaining unaware of perpetrators'

\footnotetext{
${ }^{158}$ Hudson, above n 2, p 247.

${ }^{159}$ Cossins, above n 2, p 365. It is notable that one sexual offence victim whose experience of conferencing was more negative than positive overall was 'drawn into, manipulated, and groomed by [the offender] for sexual relations over a considerable period of time'. See K Daly and S Curtis-Fawley, 'Justice for Victims of Sexual Assault: Court or Conference?' in K Heimer and C Kruttschnitt (eds), Gender and Crime: Patterns of Victimization and Offending (New York: New York University Press, 2006) p 230, p 257.

${ }^{160}$ K Pranis, 'Restorative Justice Values and Confronting Family Violence', in Strang and Braithwaite, above n 2, p 23, p 37 (emphasis added).

${ }^{161}$ See J Stubbs, Domestic Violence and Women's Safety: Feminist Challenges to Restorative Justice in Strang and Braithwaite, above n 2, p 42, p 58 (in the context of men who abuse their partners). On the manipulative setting up of situations to enable grooming, see McAlinden, above n 18, p 126.

162 Whilst there is currently no research to support this position, it is supported by the leading clinical psychology expert on child pornography offending and victims, Dr Ethel Quayle (personal communication, 30 October 2015).
} 
identities is more damaging. ${ }^{163}$ There is a need for further research in this area, but even if other evidence were produced indicating that receiving an apology has more positive restorative effects for $\mathrm{CP}$ victims than negative effects, it will often be impossible for the offender to apologise since many CP victims remain unidentified, as will be discussed shortly.

For these reasons, it would seem more appropriate for a new mode of reparation to operate within or alongside the formal criminal justice system, in a way that avoids bringing victim and offender together. Whilst recognising that further work is required to create a new model of restorative justice which would put into practice the paradigm of reparation that has been advocated, ${ }^{164}$ one possible way forward will be sketched here. A central pot of financial redress for CP victims could be established which all convicted offenders pay into, but which also receives state contributions to better guarantee the availability of sufficient funds. There could be set sums that defendants pay into the pot for: abuse; creation; distribution; creation by downloading; ${ }^{165}$ and possession of images, ${ }^{166}$ and defendants who plead guilty or are convicted would have to pay the set sum regardless of whether their victims are identifiable. The system could function in the same way as the current CICS, in that victims of CP crimes could apply to the scheme's authority. Unlike the current system of compensation orders in criminal proceedings, this would enable the provision of material reparation where victims are only identified after a particular defendant's trial. Moreover, where it is established that images recovered by police feature particular CP victims, these victims could apply for redress regardless of whether the offenders who originally created or distributed the images have been identified.

\footnotetext{
${ }^{163}$ Leonard, above n 29, p 251.

164 The exact nature and practicalities of such a model of reparation is the subject of the author's ongoing research.

165 See above $n 56$.

${ }^{166}$ See also Jacques, above n 128, p 1191.
} 
There would need to be a clear explication of the nature of the harm and wrong that victims suffer, as illustrated in the paradigm proposed earlier, both to justify the existence of the scheme and to avoid the implication that material reparation in and of itself repairs the wrong committed. Thus, alongside personal injuries (physical harm caused by the sexual abuse, mental injury and psychiatric conditions), the wrong should be framed as a violation of privacy and dignity and, for CP victims who are aware of the availability of the image(s), further mental suffering, repression, feelings of shame and guilt, recurring invasions of privacy and violations of autonomy and dignity. Significantly, a scheme involving a central pot of financial redress could be advantageous because it reflects the collective responsibility of abusers/creators, distributors and downloaders for this overall harm caused to the victim. It would also avoid the difficulty of proving the percentage of particular defendants' contributions to victims' overall harm. In addition, because reparation would come from offenders (albeit with state support), the symbolic value of emphasising the wrong that they have committed against victims would be retained.

However, whilst developing a scheme such as that sketched above might address the matter of material reparation for CP victims, financial redress must be considered alongside the larger question of how more can be done to aid victims' restoration. According to the afore-mentioned UN Optional Protocol, 'States Parties shall take all feasible measures with the aim of ensuring all appropriate assistance to victims of [CP], including... their full physical and psychological recovery'. ${ }^{167}$ There are two particular issues which must be tackled in order for the UK to fulfil this obligation: the challenges raised by victim

${ }^{167}$ See above n 7, Article 9[3] (emphasis added). 
identification and providing appropriate counselling support for those victims who are identified.

The identification of victims is an ongoing problem ${ }^{168}$ and involves a difficult and time consuming process. ${ }^{169}$ Whilst a new national database was recently launched which should enable investigators to identify known images, classify content and flag up new images more efficiently, questions have been raised as to whether there are sufficient resources in place for the system to operate in the long-term. ${ }^{170}$ Successful victim identification also presents difficult ethical issues as the victim may remain unaware that her sexual abuse was recorded and, if it was a very young child whose sexual abuse is featured in the image, she may also be unaware of the actual abuse. If such a victim is identified some or perhaps many years after the event, ought she to be informed of the crimes committed against her by the police to enable her to seek reparation from the offender? This immensely difficult question raises the issue of the victim's interest in knowing information pertaining to herself and her interest in not knowing this information. ${ }^{171}$ Her interest in knowing can be based on notions of self-

${ }^{168}$ G Holland, 'Identifying Victims of Child Abuse Images: An Analysis of Successful Identifications' in E Quayle and M Taylor (eds), Viewing Child Pornography on the Internet: Understanding the Offence, Managing the Offender, Helping Victims (Lyme Regis: Russell House Publishing, 2005), p 77.

169 See Gillespie, above n 27, pp 332-333 and 360; J Carr and Z Hilton, 'Combating Child Abuse Images on the Internet: International Perspectives' in J Davidson and P Gottschalk (eds) Internet Child Abuse: Current Research and Policy (Abingdon: Routledge, 2011), p 72.

${ }^{170}$ See 'Child abuse database containing millions of images to launch' BBC News 2 December 2014, at http://www.bbc.co.uk/news/technology-30175102 (last visited 9 December 2015).

${ }^{171}$ The right to know and the right not to know have been explored predominantly in medical law and ethics in relation to processing genetic information and are most commonly seen to be connected to rights of autonomy and privacy (see, eg, P Borry, M Shabani and HC Howard, 'Is There a Right Time to Know? The Right Not to Know and Genetic Testing in Children' (2014) 42 Journal of Law, Medicine and Ethics 19, pp 21-22; V Chico, 'Requiring Genetic Knowledge: a Principled Case for Support' (2015) 35 LS 532). The marked difference is that, in the genetic context, the person who has undergone genetic testing is already aware there is sensitive information about herself that she may or may not wish to know. She then exercises her autonomy in deciding whether or not to know the results, taking into account the reasons in favour of knowing and against knowing. In contrast, the unaware victim of sexual abuse and CP has no knowledge of the existence of the information about the crimes committed against her and is therefore unable to exercise her autonomy and weigh up the reasons for and against knowing it without first being informed of its existence by the police. Thus, in order to exercise a right to know, she needs to be informed of the existence of information about herself and it is extremely difficult to envisage how she could be alerted to its existence without its essence being revealed (see G Laurie, 'Recognizing the Right Not to Know: Conceptual, Professional and Legal Implications' (2014) 42 Journal of Law, Medicine and Ethics 53, p 54). Consequently, it would appear more 
authorship of her life and experiences. ${ }^{172}$ This interest may lead to the argument that the police have a disclosure responsibility to empower her to take control over this previously unknown life experience and take action to bring the offender to account to her personally for the wrong and harm he has perpetrated. Yet the disclosure of her abuse and the CP is highly likely to cause serious distress and psychological harm, even if this is dealt with sensitively by the police. ${ }^{173}$ Thus, she also has an interest in not knowing this information in order to avoid the harm this knowledge will cause. There is next to no research on how to resolve this dilemma. ${ }^{174}$ Prior to the implementation of a reparation scheme such as that outlined above, research is therefore needed to ascertain whether it is appropriate to disclose the sexual abuse and the existence of images to unaware victims and the best way in which to do so, in order that police policy can offer some means to resolve the conflict between the victim's interest in knowing and in not knowing. ${ }^{175}$

Turning to those victims who are aware of the existence of images, whilst some will have come forward to disclose their abuse there will be other victims who have chosen to deal with what has happened to them without disclosure, for whatever reasons. ${ }^{176}$ In some such cases, police intervention could significantly affect victims' 'rights to retain control over their own experiences'. ${ }^{177}$ Conversely, careful and sensitive police intervention could lead to a child

difficult to respect the CP victim's right to know without defeating her right not to know. Similarly, if the police choose to act in accordance with the CP victim's right not to know, they deny her right to know the information.

${ }^{172}$ See, eg, J Wilson, 'It's Time to Stop Worrying About Paternalism in Health Policy', in T Schramme (ed), New Perspectives on Paternalism and Health Care (London: Springer, 2015) 203, pp 214-215.

${ }^{173}$ See also Taylor and Quayle, above n 4, pp 206-207.

${ }^{174}$ T Palmer, 'Behind the Screen: Children who are the Subjects of Abusive Images' in Quayle and Taylor, above $\mathrm{n}$ 168, p 61, p 65: '[w]e know little about the impact of such a revelation on the now adult "child victim” and need to think strategically about why and when such a disclosure may be necessary...'.

${ }^{175}$ Police policy guidelines on the identification of now older victims have been said to be "poorly thought through and expressed': Taylor and Quayle, above n 4, p 207.

${ }^{176}$ Reasons cited for non-disclosure in one study were 'guilt' and 'fear of the threats of the perpetrator'. von Weiler et al., above n 21, p 213.

${ }^{177}$ Taylor and Quayle, above n 4, p 206. 
disclosing abuse when, previously, he had been too scared to do so and could enable law enforcement to bring a perpetrator to justice. ${ }^{178}$

Moreover, further investment is needed in victim counselling. There is a paucity of research on appropriate treatment and therapy for CP victims. ${ }^{179}$ However, according to that which is most recently available, therapists consider working with CP victims to be more complex than working with other child sexual abuse victims and 'are still at a loss as to how to treat [CP victims] to the fullest extent'. ${ }^{180}$ Writing in 2014, Martin commented that there are 'no evidence-based guidelines about how to respond to the victims' and, of the fourteen practitioner participants in her study, only two had received training on online CP. ${ }^{181}$ Indeed, her 'prevailing finding was that most practitioners did not have a clear understanding of [online CP] or the potential effects on child victims'. ${ }^{182}$ The general view amongst participants was that the usual trauma and treatment approaches for victims of child sexual abuse would not be sufficient for CP victims because of the added dimension of the permanent availability of the images online. ${ }^{183}$ Furthermore, there was a concern that if CP had been a component of the sexual exploitation experienced by victims whom they had treated, this would have been missed because 'they would not know to ask the child about

178 See 'Charity boss Simon McCarty jailed for child abuse' BBC News 7 September 2012, at http://www.bbc.co.uk/news/uk-england-19526503 (last visited 9 December 2015) for a case in point.

${ }^{179}$ Martin, above n 34, p3.

${ }^{180}$ von Weiler et al., above n 21, p 221. See also See also J Martin, “'It’s Just an Image, Right”: Practitioners’ Understanding of Child Sexual Abuse Images Online and Effects on Victims' (2014) 35 Child \& Youth Services 96.

${ }^{181}$ Martin, ibid, pp 98 and 99. See also British Association of Social Workers, 'Social workers need more support in dealing with online abuse of children’ (2013) at https://www.basw.co.uk/news/article/?id=556 (last visited 9 December 2015).

182 Ibid, p 101.

${ }^{183}$ Martin, above n 34, p 5. Indeed, Martin concludes that because '[c]urrently, trauma treatment models in social work focus on managing post-trauma symptoms[, a] conceptual shift is required to recognise the various needs of children who know, or may become aware, that images of their abuse are in circulation online... this conceptual shift should be based on developmental needs (e.g. how the child "makes meaning" of the potential permanence and accessibility of the online image) and include the recalibration of trauma frameworks...).' Martin, above n 34, p 13. 
abuse images'. ${ }^{184}$ This suggests that inadequacies in therapists' training may pose further problems for victim identification. And the matter of counselling raises once more the question of the victim's interest in knowing and in not knowing: one participant was troubled by the ethical ramifications if their counselling revealed the existence of images to an unaware child. ${ }^{185}$ The limited available research on practitioners' experiences of counselling $\mathrm{CP}$ victims therefore suggests that we cannot even begin to tackle the challenge of assisting victims in their recovery without better investment in training for practitioners. A new mode of restorative justice for $\mathrm{CP}$ victims would have to be responsive to this matter.

In conclusion, this paper has taken the first step in the process of illustrating how restorative justice principles could deal with the harm caused to CP victims and shape the reparation that should be provided to them. A mode of reparation reflecting restorative justice would recognise the symbolic significance of emphasising the wrong that offenders have committed against victims and take into account offenders' collective responsibility for the harm caused. Further steps are required in order to give fuller shape to a new model of material reparation that could put into practice the suggested scheme outlined here. However, in order to fulfil the demands of restorative justice, any such system would need to be accompanied by more investment in victim identification and appropriate, tailored counselling to facilitate victims' restoration in the broader context. Until then, achieving restorative justice for victims of CP is only ever likely to be an ideal rather than a reality.

\footnotetext{
184 Ibid, p 6.

185 Ibid, p 10.
} 